\title{
Erratum
}

Lee Bohnhoff and Mary Dalrymple*

\section{Erratum to: Applicatives in Yąg Dii: Morphological and syntactic implications}

https://doi.org/10.1515/jall-2018-9012

Erratum to: Lee Bohnhoff / Mary Dalrymple. "Applicatives in Yąg Dii: Morphological and syntactic implications", in: JALL: issue 39, volume 2 (2018), DOI https://doi.org/10.1515/jall-2018-0006.

As the original DOI (https://doi.org/10.1515/jall-2018-0006) was a duplicate, a new DOI has now been assigned. The new DOI is https://doi.org/10.1515/jall2018-0012).

*Corresponding author: Mary Dalrymple, Faculty of Linguistics, Philology and Phonetics, University of Oxford, Oxford, England, E-mail: mary.dalrymple@ling-phil.ox.ac.uk Lee Bohnhoff, Division for Global Mission, Evangelical Lutheran Church in America, Chicago, USA, E-mail: baayagdii@yahoo.com 